\title{
Performance of some apricot (Prunus armeniaca L.) germplasm accessions for fruit quality traits in Himachal Pradesh
}

\author{
Dinesh Singh ${ }^{1}$, Ankush Thakur ${ }^{1}$, K. Kumar ${ }^{1}$, J. C. Rana ${ }^{2 *}$ M.G. Bhoyar ${ }^{1}$ and Nirmla \\ Chauhan $^{1}$ \\ ${ }^{1}$ Department of Fruit Science, Dr YS Parmar University of Horticulture and Forestry, Nauni, Solan-173230 (HP), \\ INDIA \\ ${ }^{2}$ National Bureau of Plant Genetic Resources, ICAR, Pusa campus, New Delhi, INDIA \\ *Corresponding author. E-mail: fruitbreeder@rediffmail.com
}

Received: April 19, 2016; Revised received: November 7, 2016; Accepted: February 2, 2017

\begin{abstract}
The present investigation was carried out in field gene bank of NBPGR Regional Station Phagli, Shimla during the year 2014-15. Twenty accessions of Prunus armeniaca L namely St. Ambroise, Wenatchee, Nugget, Stirling, Nari, Harogem, Rakovslik, Viva Gold, IC-432145, Erevani, Safed Perchinar, KS-1, AS-1, AS-2, NJ-A96, Jordan Early, Vitillo, Shahib, Kalola and Anglo Arsani were evaluated for their tree, foliage, floral and fruit characters. St. Ambroise recorded maximum tree height $(10.10 \mathrm{~m})$ whereas minimum $(2.47 \mathrm{~m})$ was in Stirling. Shedding of leaf started from $29^{\text {th }}$ October (Nugget) and extended till $27^{\text {th }}$ November (Vitillo). Time of full bloom extended from $16^{\text {th }}$ March in Shahib to $23^{\text {rd }}$ March in Safed Perchinar. The longest duration (22 days) of flowering was recorded in Erevani and shortest ( 9 days) in Wenatchee. Time of fruit maturity was early $\left(25^{\text {th }}\right.$ May) in Shahib and late $\left(26^{\text {th }}\right.$ June) in Vitillo. Largest and heaviest fruits were observed in St. Ambroise (77.59 g) whereas smallest and lightest fruits were in Viva Gold $(19.37 \mathrm{~g})$. Maximum pulp to stone ratio was recorded in Safed Perchinar (33.21) and minimum in Nari (15.57). TSS content was maximum $\left(19.56^{\circ} \mathrm{B}\right)$ in Nari whereas minimum $\left(10.73^{\circ} \mathrm{B}\right)$ in Anglo Arseni. Titratable acidity was recorded maximum (1.86 \%) in AS-1 and minimum $(0.76 \%)$ in IC 432145 . Total sugar content ranged from 8.40 per cent in Anglo Arseni to 16.53 per cent in Nari. Total phenol content was maximum (89.57 $\mathrm{mg} / 100 \mathrm{~g})$ in AS-1 and minimum $(70.41 \mathrm{mg} / 100 \mathrm{~g})$ in IC432145. From the present investigation it may be concluded that St. Ambroise, Nari and Shahib can be used for gene source for developing new hybrid cultivars and St. Ambroise may be suggested for cultivation in wet temperate condition of Himachal Pradesh for its better quality.
\end{abstract}

Keywords: Apricot, Characterization, Evaluation, Gene source

\section{INTRODUCTION}

Introduction and characterization of new crop varieties has for long prevailed as the most favoured method of fruit crop improvement necessitated by the bottlenecks involved in this very tedious and time consuming endeavour. Thereby the importance associated with the evaluation of introduced plant material in the targeted agro-ecological conditions can never be overlooked. The apricot (Prunus armeniaca L.) is one of the most important and delicious fruit of temperate regions of Himachal Pradesh. The fruits of apricot are attractive, delicious and highly nutritious. The total area under apricot cultivation in Himachal Pradesh is 3577 ha with the production of 3165 MT during 2013-2014 (Anonymous, 2014). Apricots are enjoyed as a fresh fruit but also dried and processed into jam, nectar and squash. There are certain apricot cultivars such as Shakarpara, Nugget, Kaisha, Ladakhi, etc. which have better fruit quality and are grown in higher hills, but under mid hill conditions, where these cultivars do not fruit better, cultivars like NewCastle, Shipley's Early and EMA have been found to perform better than others (Yilmaz et al., 2012).

Amongst all, New Castle is the commercially accepted mid-season cultivar of apricot for the mid hills. It has good demand for both table and processing purpose because of its excellent flavour and quality. However, with the advancement of age, its fruit size and quality decreases which has less demand in market. Moreover, the fruit of apricot is highly perishable in nature as it has a short shelf-life at ambient temperatures. Short shelf life of the fruits represents a serious constraint for efficient handling, transportation and marketing chain of the produce. As in many other crops, improvement of size, appearance and internal quality of apricot fruits are important objectives pursued by researchers (Tondon, 2006).

Although, the area and production of apricot have registered a manifold increase as is evident from the fact that apricot occupied only an area of 2400 ha with the production of 7000 MT (Anonymous, 1979) which is increased to 10000 ha with the production of $8647 \mathrm{MT}$ (Anonymous, 2013) yet the productivity remains the 
main concern as it is very low as compared to developed countries.

With a sudden upsurge of global warming standard apricot cultivars, failed to meet the requisite chilling requirements in wet temperate regions of H.P. posing the risk of crop failure thereby leading to huge economic losses to the farmers. This situation may only be countered by broadening the base of germplasm through introduction and evaluation of new varieties of apricot of H.P. through varietal diversification not only to meet the demand of fresh fruit market but also to provide raw material for longer time to agro processing units (Akin et al., 2008). Keeping in mind the above and to provide an array of apricot varieties present study was carried out on some apricot germplasm accessions available in the field gene bank of NBPGR, Regional Station Phagli, Shimla with the objective to describe and evaluate apricot germplasm for fruit quality characteristics.

\section{MATERIALS AND METHODS}

The present investigations were carried out in the field gene bank of National Bureau of Plant Genetic Resources, Regional Station Phagli, Shimla during the year 2014-15 at an elevation of $1924 \mathrm{~m}$ amsl experiencing wet temperate climate. The genotypes undertaken for studies included St. Ambroise, Wenatchee, Nugget, Stirling, Nari, Harogem, Rakovslik, Viva Gold, IC-432145, Erevani, Safed Perchinar, KS-1, AS1, AS-2, NJ-A96, Jordan Early, Vitillo, Shahib, Kalola and Anglo Arsani. Three trees of each germplasm accession were selected.

Morpho-physical fruit characteristics: To study fruit characters, 30 representative fruit samples (10 in each replication) were taken at optimum maturity. The average length and breadth was measured following standard procedure. The weight of ten fruits under three replicates of each genotype was recorded and the average weight per fruit was calculated. The surface colour, fruit skin colour and fruit flesh colour of the fruits were observed by comparing with the colour charts of the colour charts of the Royal Horticultural Society, London. Optimum maturity date was recorded in each genotype as time of fruit maturity. Number of days from full bloom to harvest was counted from the date of full bloom to the date of harvest. Fruit firmness was measured in $\mathrm{kg} / \mathrm{cm}^{2}$ and average of five fruits (each of 3 replicates) was worked out.

The stone size was recorded by measuring the length, breadth and thickness. Stone shape was classified as per IBPGR (1984) apricot descriptors as rounded, ovate, oblong, elliptic and elongated. The weight of ten stones under three replicates of each genotype was recorded and the average weight per stone was calculated. Adherence to flesh to stone was observed visually in each genotype and classified as clingstone, semiclingstone and freestone. Pulp/stone ratio was worked out by dividing the weight of the fruit pulp by the weight of stone. Presence of grooves/pits and shape of apex was observed visually in each genotype.

Biochemical fruit character: The total soluble solid content of fruits was determined with by Erma hand refractometer (0-32 ${ }^{\circ}$ Brix). Acidity, sugars and ascorbic acid were estimated as per the standard procedures (A.O.A.C. 1970). Sugar/acid ratio was worked out by dividing per cent total sugar with per cent titratable acidity. Total phenols were determined by FolinCiocalteu procedure given by Singleton and Rossi (1965).

\section{RESULTS AND DISCUSSION}

Morpho-physical fruit characteristics: Maximum fruit length $(55.97 \mathrm{~mm})$ and fruit breadth $(54.19 \mathrm{~mm})$ were recorded in St. Ambroise whereas minimum fruit length $(31.79 \mathrm{~mm})$ and fruit breadth $(27.98 \mathrm{~mm})$ was observed in Nugget (Table 1).

Heaviest fruits were found in St. Ambroise having $77.59 \mathrm{~g}$ average fruit weight and lightest fruits were observed in Viva Gold having $19.37 \mathrm{~g}$ average fruit weight. All the accessions recorded significant differences. Verma et al. (2009) recorded lesser fruit weight in St. Ambroise. These variations may be due to climatic conditions and lesser crop load during the year 2014. The fruit firmness was found to be maximum $7.53 \mathrm{~kg} / \mathrm{cm}^{2}$ in Erevani which was at par with St. Ambroise, IC 432145, Nari and Viva Gold whereas minimum $\left(3.33 \mathrm{~kg} / \mathrm{cm}^{2}\right)$ was in AS-1 (Table 1). This is an important factor taken into consideration where fruits have to be transported over long distances and local markets are not available. The colour of fruit (flesh and skin) as well as the adherence of stone to pulp are also important indices to differentiate between various apricot cultivars and to some extent are considered as indices of maturity. The fruit flesh colour was observed to be in Yellow Orange group (23 A) in St. Ambroise, Safed Perchinar, AS-1, AS-2, Vitillo, Anglo Arseni and (23 B) in NJ-A 96, Kalola; Orange Group (24 A) in Wenatchee, Nugget, Viva Gold, IC 432145, KS-1, Jorden Early, Shahib and (24 B) in Stirling, Nari, Harogem and (25 A) in Rakovslik and (25 B) in Erevani. The Fruit skin colour was observed to be in Yellow Orange Group (21 A) in St. Ambroise, Stirling, Harogem, Rakovslik, IC432145, Erevani, AS-1, AS-2, NJ-A 96, Vitillo, Kalola; (21 B) in Wenatchee, Nugget, Safed Perchinar, KS-1 and (21 C) in Anglo Arseni; Yellow Orange Group (23 A) in Nari, Jorden Early, Shahib and Orange Group; (24 A) in Viva Gold. However, in present study the apricot accessions exhibited no significant variation in fruit skin and flesh colour except the slight variation was observed in the shade of the colour. Such variation have also been reported by previous workers Russo and Andrea, 2004; Tondon, 2006; Asma et al., 2007; Verma et al., 2009; Bhat et al., 2013; Kamrani, 2013.

Significant differences in various fruit characters such 
Dinesh Singh et al. / J. Appl. \& Nat. Sci. 9 (1): 351 - 356 (2017)

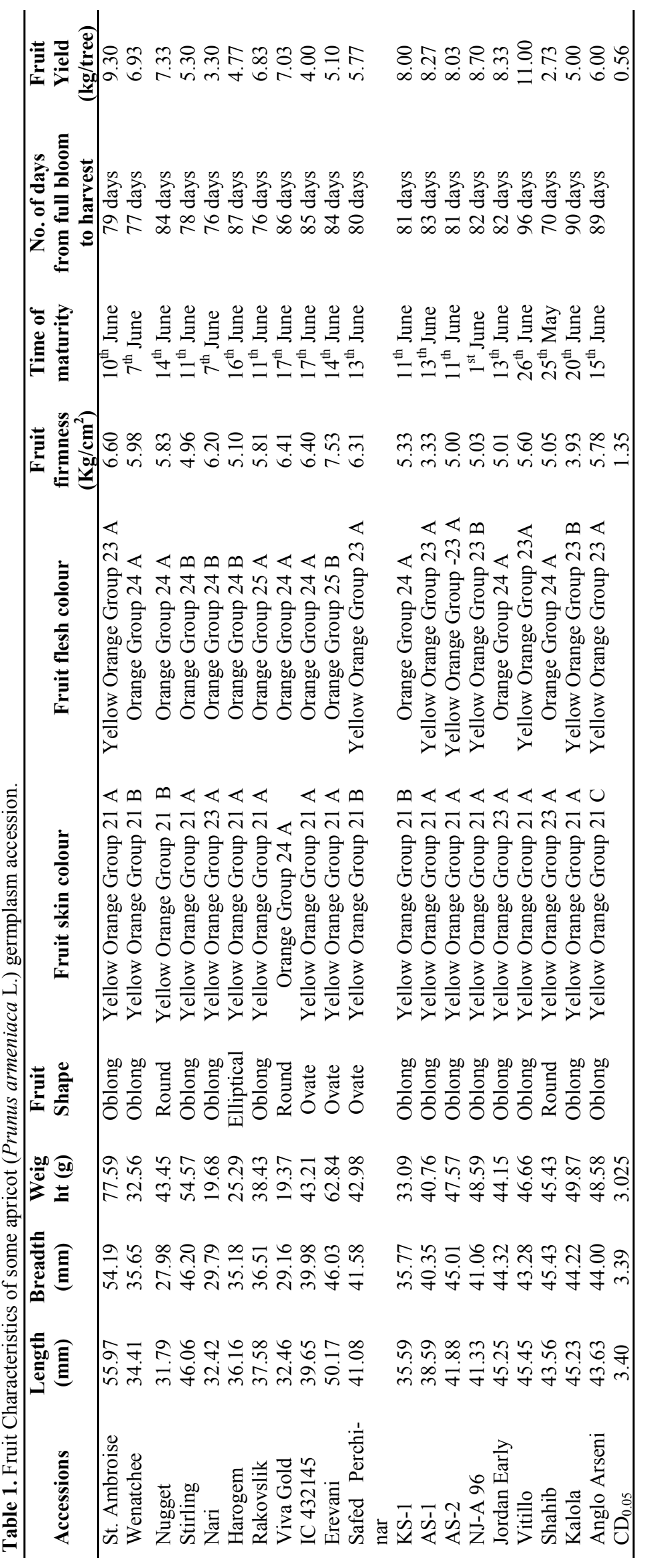


Dinesh Singh et al. / J. Appl. \& Nat. Sci. 9 (1): 351 - 356 (2017)

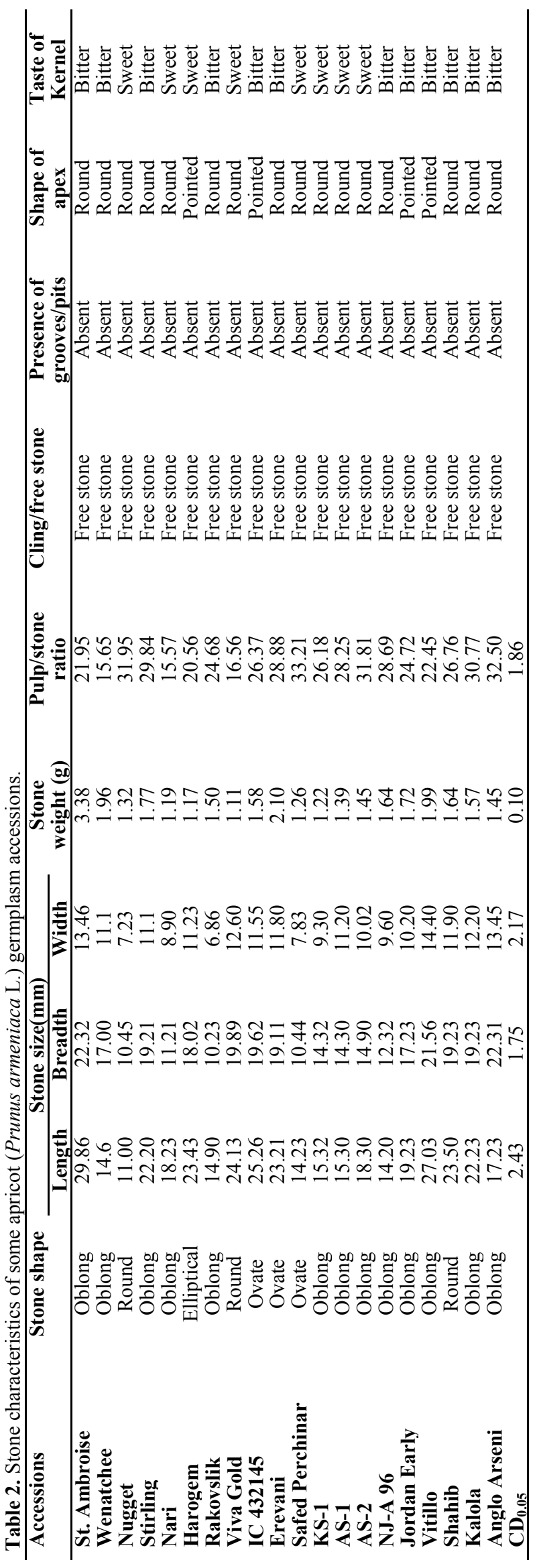

as size, weight, colour of skin and flesh were observed in apricot accessions studied. These fruit characters are detrimental in making any variety acceptable to the end users i.e. the consumers. In general domestic market has a likeness toward apricot fruits which are large in size, sweet in taste, less acidic, juicy flesh is easily separable from stone. Several workers have worked on the physical aspects of apricot (Malanczuk and Sosna, 2005; Asma et al., 2007; Milosevic et al., 2010; Bhat et al., 2013) in the past and have reported considerable variation in fruits of different apricot cultivars.

Number of days from full bloom to harvest ranged from 70 days in Shahib to 96 days in Vitillo. However according to the findings of Verma et al. (2009) number of days from full bloom to harvest in Vitillo was 103 days. Time of maturity was from 25 May in Shahib to 26 June in Vitillo.

Most of the genotypes had Oblong stone shape except Nugget, Viva Gold and Shahib (Round), IC432145, Erevani and Safed Perchinar (Ovate) and Harogem (Elliptical). Average stone length ranged from 11.00 $\mathrm{mm}$ in Nugget to 29.86 in St. Ambroise. There were significant differences among the apricot genotypes with regard to stone length (Table 2). Highest stone weight was recorded in St. Ambroise $(3.38 \mathrm{~g})$ which was followed by Erevani $(2.10 \mathrm{~g})$ and lowest in Viva Gold (1.11 g).

All the genotypes were freestone. Pulp/stone ratio is an important criterion to judge the quality of apricot fruits. It is evident from Table 2 that highest pulp/stone ratio (33.21) was found in Safed Perchinar while the ratio was lowest (15.57) in Nari. All the twenty genotypes were found to have absence of grooves and pits on the stone surface. The shape of apex was found to be round in all the genotypes except Harogem, IC 432145, Jorden Early and Vitillo which had pointed apex.

Biochemical characteristics: The TSS content in fruits ranged between $10.73{ }^{\circ} \mathrm{B}$ in Anglo Arseni and $19.56{ }^{\circ} \mathrm{B}$ in Nari. However according to Kamrani (2013) the range of TSS content from $9.9^{\circ} \mathrm{B}$ to $25.2^{\circ} \mathrm{B}$ in another set of apricot introductions. It is revealed from Table 3 that highest acidity $(1.86 \%)$ was in AS-1 followed by Shahib $(1.53 \%)$ and lowest $(0.76 \%)$ in IC 432145. These findings are in line with the results of Asma et al. (2007) and Bhat et al. (2013), in another set of varieties. The total sugar content ranged from 8.40 per cent in Anglo Arseni to 16.53 per cent in Nari. Reducing sugars varied from 7.17 per cent in Viva Gold to 10.22 per cent in Nari. Mratinic et al. (2011) recorded the range of reducing sugar from 8.49 per cent to 10.39 per cent in another set of apricot introductions. Maximum content of non-reducing sugars was 6.00 per cent in NJ-A96 and minimum $(0.62 \%)$ in Anglo Arseni. NJ-A96 was found to be statistically at par with Nari (Table 3).

The highest sugar/acid ratio recorded was 18.26 in 
Dinesh Singh et al. / J. Appl. \& Nat. Sci. 9 (1): 351 - 356 (2017)

Table 3. Biochemical characteristics of some apricot (Prunus armeniaca L) germplasm accessions.

\begin{tabular}{lccccccc}
\hline Variety & $\begin{array}{c}\text { Titratable } \\
\text { acidity (\%) }\end{array}$ & $\begin{array}{c}\text { Total soluble } \\
\text { solids }\left({ }^{\circ} \mathbf{B}\right)\end{array}$ & $\begin{array}{c}\text { Total } \\
\text { sugars } \\
\mathbf{( \% )}\end{array}$ & $\begin{array}{c}\text { Reducing } \\
\text { sugars (\%) }\end{array}$ & $\begin{array}{c}\text { Non-reducing } \\
\text { sugars (\%) }\end{array}$ & $\begin{array}{c}\text { Sugar/ } \\
\text { acid ratio }\end{array}$ & $\begin{array}{c}\text { Phenol con- } \\
\text { tent } \\
\text { (mg/100ml) }\end{array}$ \\
\hline St. Ambroise & 0.80 & 16.73 & 13.66 & 8.47 & 4.92 & 17.24 & 74.44 \\
Wanatchee & 1.00 & 15.26 & 12.31 & 7.30 & 4.74 & 12.52 & 79.07 \\
Nugget & 1.03 & 13.83 & 11.24 & 7.27 & 3.75 & 12.75 & 80.35 \\
Stirling & 0.84 & 15.33 & 12.31 & 8.14 & 3.95 & 14.71 & 76.22 \\
Nari & 0.92 & 19.56 & 16.53 & 10.22 & 5.97 & 18.26 & 78.33 \\
Harogem & 1.16 & 14.96 & 11.96 & 7.43 & 4.28 & 10.29 & 83.38 \\
Rakovslik & 1.07 & 15.83 & 13.67 & 8.05 & 4.74 & 12.30 & 82.33 \\
Viva Gold & 0.86 & 14.26 & 11.40 & 7.17 & 4.00 & 13.45 & 77.18 \\
IC 432145 & 0.76 & 16.97 & 13.33 & 8.72 & 4.36 & 18.01 & 70.41 \\
Erevani & 1.13 & 15.23 & 12.27 & 7.29 & 4.70 & 10.89 & 82.31 \\
Safed Perchinar & 1.23 & 16.61 & 13.03 & 8.24 & 4.53 & 10.58 & 84.44 \\
KS-1 & 1.23 & 15.05 & 11.83 & 7.45 & 4.14 & 9.60 & 84.51 \\
AS-1 & 1.86 & 15.53 & 12.33 & 8.42 & 3.70 & 6.74 & 89.57 \\
AS-2 & 1.40 & 14.66 & 11.80 & 7.83 & 3.75 & 8.47 & 87.31 \\
NJ-A 96 & 1.46 & 18.73 & 14.50 & 8.15 & 6.00 & 10.01 & 88.46 \\
Jordan Early & 1.16 & 15.93 & 13.36 & 8.09 & 4.99 & 11.85 & 82.41 \\
Vitillo & 1.20 & 16.70 & 13.30 & 8.02 & 4.99 & 11.17 & 83.54 \\
Shahib & 1.53 & 10.83 & 9.06 & 7.61 & 1.38 & 6.14 & 87.28 \\
Kalola & 0.90 & 12.00 & 9.66 & 8.03 & 1.55 & 11.23 & 76.83 \\
Anglo Arseni & 1.20 & 10.73 & 8.40 & 7.75 & 0.62 & 7.31 & 83.52 \\
CD 0.05 & 0.32 & 1.13 & 1.056 & 0.56 & 0.93 & 4.07 & 0.39 \\
\hline
\end{tabular}

Nari and lowest was 6.14 in Shahib. The total sugar content ranged from 8.40 per cent in Anglo Arseni to 16.53 per cent in Nari. However Bhat et al. (2013) recorded total sugars ranging from 8.65 per cent to 15.20 per cent in another set of apricot cultivars. Such variations may be due to different agro-climatic conditions influencing synthesis of biochemical constituents in the developing fruits and the duration of fruit development period. The presence of phenols is considered beneficial as far as therapeutic value of any fruit is concerned. In present study, the total phenol content varied from $70.41 \mathrm{mg} / 100 \mathrm{ml}$ in IC432145 to 89.57 $\mathrm{mg} / 100 \mathrm{ml}$ in AS-1. These findings are in consonance with those of Ali et al. (2011); Karav and Eksi (2012); Caliskan et al. (2012).

On the whole the present findings do indicate that some of these genotypes Nari (high TSS content, free stone), St. Ambroise (large and firm fruits, high TSS content, free stone), Shahib (Early maturing, free stone, Large fruits), Safed Perchinar (high pulp to stone ratio, high TSS content) and Stirling (High TSS content) do possess one or more desirable fruit quality characteristics and can be future commercial varieties provided they are tested multilocationally.

\section{Conclusion}

From the foregoing discussion, it is concluded that the results obtained are preliminary and there is further need to evaluate these apricot germplasm accessions in the subsequent years. However, the present studies does indicate that some of these accessions do possess one or more horticulturally desirable characteristics (enlisted below) and thus can be future commercial varieties provided they yield quality fruits consistently and sufficiently.

$\begin{array}{ll}\begin{array}{l}\text { Apricot } \\ \text { accessions } \\ \text { St. Ambroise }\end{array} & \begin{array}{l}\text { Distinguishing character(s) } \\ \text { Large and firm fruits, high TSS } \\ \text { content, free stone }\end{array} \\ \text { Shahib } & \begin{array}{l}\text { Early maturing, free stone, Large } \\ \text { fruits }\end{array} \\ \text { Nari } & \text { High TSS content, free stone } \\ \text { Safed } & \text { High pulp to stone ratio, high TSS } \\ \text { Perchinar } & \text { content } \\ \text { Stirling } & \text { High TSS content }\end{array}$

\section{REFERENCES}

Akin, B.E, Karabulut, I. and Topcu, A. (2008). Some compositional properties of main Malatya apricot (Prunus armeniaca L.) varieties. Food Chemistry 107: 939-948

Ali, S, Masudi, T. and Abbasi, K.S. (2011). Physio-chemical characteristics of apricot (Prunus armeniaca L.) grown in northern areas of Pakistan. Scientia Horticulturae, 130(2): 386-392

Anonymous (1979). Statistical database. http//www. fao. org.in.

Anonymous (2013). Statistical database. http//www. fao. org.in.

Anonymous (2014). Statistical database of Himachal Pradesh. http://hpplanning.nic.in/statistics\&data.html.

AOAC. (1970). Official Methods of Analysis Benjamin Franklin Statistics, Washington, D.C.

Asma, B. M., Kan, T. and Birhanli, O. (2007). Characterization of promising apricot (Prunus armeniaca L.) 
genetic resources in Malatya, Turkey. Genetic Resources and Crop Evolution, 54: 205-212

Bhat, M. Y., Padder, B. A., Wani, I. A., Banday, F. A., Ahsan, H., Dar, M. A. and Lone, A. (2013). Evaluation of apricot cultivars based on physico-chemical characteristics observed under temperate conditions. International J. Agri. Sci., 3(5):535-537

Caliskan, O., Bayazit, S. and Sumbul, A. (2012). Fruit quality and phytochemical attributes of some apricot (Prunus armeniaca L.) cultivars as affected by genotypes and season. Notulae Botanicae Horti Agrobotanici ClujNapoca, 40(2): 284-294

IBPGR. (1984). Apricot Descriptors (eds. R Gurriero and R Watkins).31p

Kamrani, R. (2013). Identity of some Iranian apricot with fruit morphological markers (Fruit Characteristics). Annals of Biological Research, 4(7): 109-114

Karav, S. and Eksi, A. (2012). Antioxident capacity and total phenolic contents of peach and apricot cultivars harvested from different regions of Turkey. International Journal of Food and Nutrition Science, 1(4): 13-17.

Malanczuk, M.L. and Sosna, I. (2005). Evaluation of several apricot cultivars and clones in the lower Silesia climatic conditions. Journal of Fruit and Ornamental Plant Research, 13: 39-48

Milosevic, T., Milosevic, N., Glisic, I. and Krska, B. (2010). Characteristics of promising apricot (Prunus armeniaca
L.) genetic resources in Central Serbia based on blossoming period and fruit quality. Horticulture Science Prague, 37:46-55

Mratinic, E., Popovski, B., Milosevic, T. and Popovska, M. (2011). Analysis of morphological and pomological characteristics of apricot germplasm in FYR Macedonia. Journal of Agricultural Science and Technology, 13: $1121-1134$

Russo, G., and Andrea, L. D. (2004). Evaluation of apricot germplasm in Southern Italy. Acta Hort., 663: 613-619.

Singleton, V.L. and Rossi, J.A. (1965). Colorimetry of total phenolics with phosphomolybedic phosphotungstic acid reagents. American J. Enology and Viticulture, 16:144158

Tondon, S. (2006). Studies on evaluation of some apricot, peach and plum introductions. M.Sc. thesis Dr. Y S P UHF, Nauni, Solan, H.P. India

Verma, V.D., Pradheep, K., Yadav, S.K. and Rana, J.C. (2009). Characterisation and evaluation studies in apricot germplasm under high hills of Himachal Pradesh. Indian J. Plant Genetic Resources, 22(1): 17-21

Yilmaz, K. U., Kargi, S. P. and Kafkas, S. (2012). Morphological diversity of the Turkish apricot. (Prunus armeniaca L.) germplasm in the Irano-Caucasian ecogeographical group. Turkish Journal of Agriculture and Forestry, $36: 688-694$ 